\title{
Polymer Film Supported Bimetallic Au-Ag Catalysts \\ for Electrocatalytic Oxidation of Ammonia Borane in Alkaline Media
}

\author{
Şükriye Ulubay Karabiberoğlu ${ }^{1}$ Çağrı Ceylan $\operatorname{Koçak}^{2} \cdot$ Süleyman Koçak $^{3} \cdot$ Zekerya Dursun $^{1}$
}

Received: 28 April 2016/Accepted: 27 May 2016/Published online: 14 June 2016

(C) The Author(s) 2016. This article is published with open access at Springerlink.com

\begin{abstract}
Ammonia borane is widely used in most areas including fuel cell applications. The present paper describes electrochemical behavior of ammonia borane in alkaline media on the poly( $p$-aminophenol) film modified with Au and Ag bimetallic nanoparticles. The glassy carbon electrode was firstly covered with polymeric film electrochemically and then, $\mathrm{Au}, \mathrm{Ag}$, and $\mathrm{Au}-\mathrm{Ag}$ nanoparticles were deposited on the polymeric film, respectively. The surface morphology and chemical composition of these electrodes were examined by scanning electron microscopy, transmission electron microscopy, electrochemical impedance spectroscopy, X-ray diffraction, and X-ray photoelectron spectroscopy. It was found that alloyed $\mathrm{Au}-\mathrm{Ag}$ bimetallic nanoparticles are formed. Electrochemical measurements indicate that the developed electrode modified by $\mathrm{Au}-\mathrm{Ag}$ bimetallic nanoparticles exhibit the highest electrocatalytic activity for ammonia borane oxidation in alkaline media. The rotating disk electrode voltammetry demonstrates that the developed electrode can catalyze almost six-electron oxidation pathway of ammonia borane. Our results may be attractive for anode materials of ammonia borane fuel cells under alkaline conditions.
\end{abstract}

Zekerya Dursun

zekerya.dursun@ege.edu.tr

1 Department of Chemistry, Science Faculty, Ege University, 35100 Bornova, Izmir, Turkey

2 Occupational Health and Safety Department, Bergama Vocational School, Dokuz Eylul University, Izmir, Turkey

3 Department of Chemistry, Science and Art Faculty, Celal Bayar University, 45040 Manisa, Turkey 


\section{Graphical Abstract}
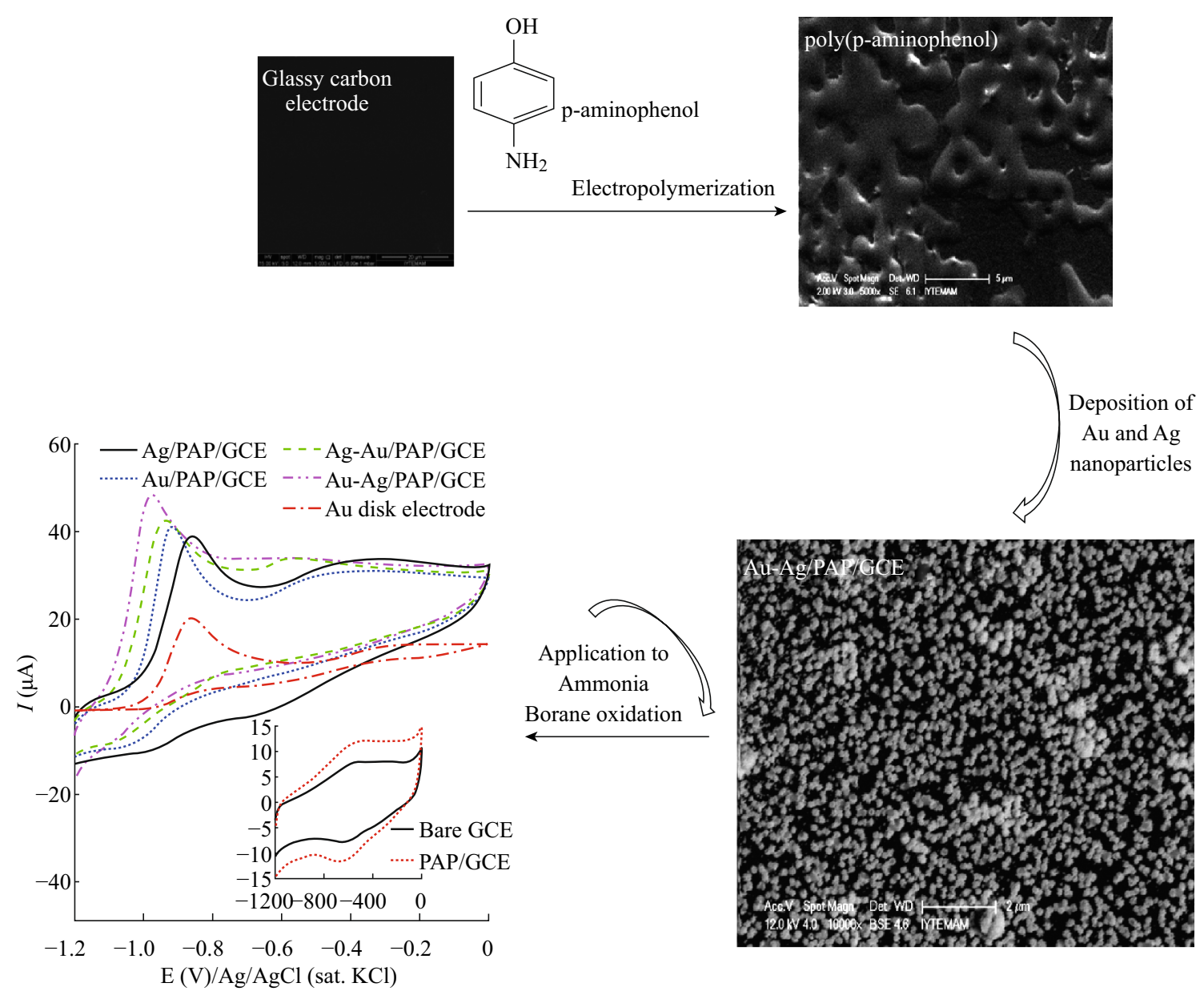

Keywords Au-Ag bimetallic nanoparticles $\cdot$ Ammonia borane $\cdot$ Electrocatalyst $\cdot$ Electropolymerization $\cdot$ Alkaline media

\section{Introduction}

Ammonia borane (or borazane, $\mathrm{NH}_{3} \mathrm{BH}_{3}$, is a crystalline, white colored, non-toxic and stable chemical, which is an alternative source for hydrogen storage due to its high hydrogen content (19.5 wt\%) and appropriate temperature for $\mathrm{H}_{2}$ release. It can be easily transported and dissolved in polar solvents such as water and methanol [1-3]. Ammonia borane $(\mathrm{AB})$ has been used in fuel cells in two ways: one is $\mathrm{H}_{2}$ formed hydrolysis of $A B$ source [4-6] and another is $\mathrm{AB}$ direct electrooxidation [7]. The hydrolysis of $\mathrm{AB}$ is unwanted in $A B$ electrooxidation reaction since the $\mathrm{H}_{2}$ evolution in the system not only reduces the energy density of fuel cell but also leads to the safety problems. The hydrolysis reaction of $\mathrm{AB}$ has been observed in the presence of some common catalysts such as Co [8, 9], Pd [10], $\mathrm{Ru}$ [11], Ni [12], Co-Pt [13], NiCo-Pt [14], etc. Obviously, to avoid the hydrolysis of $\mathrm{AB}$, these metal catalysts should not be used in ammonia borane electrooxidation reaction directly.

The direct electrooxidation of $\mathrm{AB}$ is assumed as chemical or electrochemical reaction, which is initiated with the dissociation of $\mathrm{AB}$ in alkaline solution to form hydroxyl-borohydride $\left(\mathrm{BH}_{3}(\mathrm{OH})^{-}\right)$and ammonia $\left(\mathrm{NH}_{3}\right)$ (Eq. 1). The $\mathrm{BH}_{3}(\mathrm{OH})^{-}$intermediate is then oxidized to form $\mathrm{B}(\mathrm{OH})_{4}^{-}$with a yielding of total six electrons related to the maximal efficiency process $[15,16]$ (Eq. 2):

$$
\begin{aligned}
& \mathrm{NH}_{3} \mathrm{BH}_{3_{(\mathrm{aq})}}+\mathrm{OH}_{(\mathrm{aq})}^{-} \rightleftarrows \mathrm{NH}_{3_{(\mathrm{aq})}}+\mathrm{BH}_{3}(\mathrm{OH})_{(\mathrm{aq})}^{-} \\
& \mathrm{BH}_{3}(\mathrm{OH})_{(\mathrm{aq})}^{-}+6 \mathrm{OH}_{(\mathrm{aq})}^{-} \rightleftarrows \mathrm{B}(\mathrm{OH})_{4_{(\mathrm{aq})}^{-}}^{-}+3 \mathrm{H}_{2} \mathrm{O}+6 \mathrm{e}^{-} .
\end{aligned}
$$

The electrooxidation of $\mathrm{AB}$ may proceed through different paths as multielectron process, generally depending 
on the electrode material and $\mathrm{pH}$ of the supporting electrolyte. In order to hinder hydrolysis reaction of $\mathrm{AB}$, the electrode material is generally inactive for hydrolysis by increasing the $\mathrm{pH}$ of supporting electrolyte. Au-based electrodes are good catalysts for direct electrochemical oxidation of $\mathrm{BH}_{3}(\mathrm{OH})^{-}$and show poor catalytic activity with respect to its hydrolysis over a certain concentration range [16-18]. The direct electrochemical oxidation of AB (Eqs. 1, 2) has been studied on Au microdisk and Au disk electrodes in alkaline solutions [17, 18]. In another study, amorphous core of $\mathrm{Fe}$ in $\mathrm{Fe}-\mathrm{Pt}$ core-shell nanoparticles showed high catalytic activity towards $\mathrm{AB}$ oxidation [19].

Gold nanoparticles are remarkable examples of nanoscaled electrocatalysts with new properties that have been used in fuel cells [20-23], sensors [24-26], as well as many other applications due to their small dimensional size, good stability, and excellent catalytic activity. Silver nanoparticles are also widely used in electrochemistry as electrode materials due to their high catalytic activity, novel optical property, and low cost compared to other noble metals [27-31]. In our previous study, Ag nanoparticles were synthesized on poly(thiophene)-modified glassy carbon electrode (GCE) surface using cyclic voltammetry (CV) and then applied to the electrocatalytic caffeic acid oxidation [32].

Bimetallic nanoparticle-modified electrodes have been studied extensively due to their improved catalytic performance owing to their synergistic and electronic effects [33-37]. Synthesis of bimetallic particles can be carried out through various methods, such as electroless plating [37], surface reaction [38], seeding-mediated synthesis [39], self-assembly, and electrochemical methods [40, 41]. Among them, electrochemical synthesis is an easy approach in preparing bimetallic surfaces by controlling the impurities, particle sizes, and the amount of modifier components. Metal nanoparticles need a supporting material such as carbon nanotubes, graphene, or conducting polymers in order to maintain their stability and physical properties [42, 43].

$\mathrm{Au}-\mathrm{Ag}$ bimetallic catalysts have concerned much attention in recent years owing to their electronic, optical, and catalytic properties which differ from those of individual $\mathrm{Au}$ and $\mathrm{Ag}$ mono metals. $\mathrm{Au}-\mathrm{Ag}$ bimetallic catalysts have been widely used for catalytic applications [44]. Reduced graphene oxide supported $\mathrm{Au}-\mathrm{Ag}$ bimetallic catalyst was found to have higher electrocatalytic activity for glucose compare $\mathrm{Au}$ and $\mathrm{Ag}$ monometal catalysts [45]. In another study, grapheme was used for supporting of sonochemical synthesis of $\mathrm{Au}-\mathrm{Ag}$ bimetallic nanoparticles to improve the catalytic activity of graphene oxide for investigation of 4-nitrophenol [46]. Au$\mathrm{Ag}$ alloy catalyst was also supported on mesoporous aluminosilicate for use in low-temperature $\mathrm{CO}$ oxidation with high stability [47]. In addition, $\mathrm{Au}-\mathrm{Ag}$ bimetallic nanoparticle-modified glassy carbon electrode was used as $\mathrm{H}_{2} \mathrm{O}_{2}$ sensor, which was directly deposited on GCE surface by CV [48]. Another sensing application is that pyrene determination on $\mathrm{Au}-\mathrm{Ag}$ bimetallic nanoparticlemodified poly(pyrrole) film GCE in which $\mathrm{Au}$ and $\mathrm{Ag}$ nanoparticles were successfully synthesized by co-precipitation method [49].

To the best of our knowledge, the present study is the first report for the electrochemical oxidation of $\mathrm{AB}$ at electrochemical fabrication of $\mathrm{Au}-\mathrm{Ag}$ nanoalloy on PAP surface. The poly ( $p$-aminophenol) film glassy carbon electrodes (PAP/GCE) were modified with $\mathrm{Au}-\mathrm{Ag}$ bimetallic nanoparticles by electrochemical techniques for catalytic oxidation of $\mathrm{AB}$ in alkaline solution. The morphological, electrical, and chemical properties of all electrodes were investigated. The electron-transfer number during ammonia borane oxidation was also calculated by using rotating disk electrode and chronoamperometry studies.

\section{Experimental}

\subsection{Reagents}

AB was purchased from Alfa Aesar. Standard solutions of $\mathrm{AB}\left(0.1 \mathrm{~mol} \mathrm{~L}^{-1}\right)$ were freshly prepared by dissolving the required amount of reagent in ultrapure water. $\mathrm{NaOH}$ was used as a supporting electrolyte obtained from Raidel De Haen. The $p$-aminophenol was obtained from Fluka and used without further purification. Sodium dodecylsulfate (SDS), $\mathrm{HClO}_{4}, \mathrm{AgNO}_{3}$, and $\mathrm{HNO}_{3}$ were of analyticalreagent grade and was supplied from Sigma, Carlo Erba, and Merck, respectively. Chloroauric acid solution was prepared by dissolving the $\mathrm{Au}$ wire $(99.999 \%$ in purity, Tanaka Kikinzoku Kogyo Co., Ltd.) in a mixture of concentrated $\mathrm{HNO}_{3}: \mathrm{HCl}$ (volume ratio of 1:3). All of the solutions were prepared by using ultrapure water with minimum resistance of $18 \mathrm{M} \Omega \mathrm{cm}^{-2}$ from Milli-Q system. All experiments were carried out at ambient temperature and under highly pure nitrogen flow over the solution during electrochemical experiments.

\subsection{Instruments}

Voltammetric measurements were carried out using BAS100B/W Electrochemical Analyzer and Autolab 302N Voltammetric Analyzer equipped with three electrode system consisted of the as-synthesized working electrodes (GCE, PAP/GCE, Ag/PAP/GCE, Au/PAP/GCE, and Au$\mathrm{Ag} / \mathrm{PAP} / \mathrm{GCE}$ ), an auxiliary electrode (Pt wire) and reference electrode $(\mathrm{Ag} / \mathrm{AgCl}$ (sat. $\mathrm{KCl})$ ). Glassy carbon electrode (with a diameter of $3 \mathrm{~mm}, 0.0707 \mathrm{~cm}^{2}$ geometric 
area) was purchased from BASi. Cyclic voltammetry, chronoamperometry modes, and rotating disk electrode were utilized throughout the studies.

The morphology and size of synthesized samples were determined by employing Philips XL 30 SFEG scanning electron microscopy (SEM) and Tecnai G2 F20 S-TWIN transmission electron microscopy (TEM). The elemental analysis was performed with an energy dispersive X-ray (EDX, Oxford). The X-ray photoelectron spectroscopy (XPS) measurements of the $\mathrm{Au}-\mathrm{Ag}$ nanoparticle-modified PAP/GCE was carried out with a Thermo K-AlphaMonochromated high-performance XPS spectrometer. The surface layer kinetics of modified electrodes were evaluated on Autolab $302 \mathrm{~N}$ electrochemical impedance spectroscopy (EIS). X-ray diffraction(XRD) patterns of the $\mathrm{Au}-\mathrm{Ag} / \mathrm{PAP}$ film electrode were obtained by $\mathrm{X}$-ray diffraction analyses using PANALYTICAL Empyrean diffractometer with $\mathrm{Cu}-\mathrm{K}$-Alpha1 radiation (15406 Ao; $40 \mathrm{kV}, 40 \mathrm{~mA}$ ) and the samples were scanned from 5 to $902 \theta$ in step sizes of 00130 and scan step time $14,892 \mathrm{~s}$.

\subsection{Preparation of Au-Ag Nanoparticle-Modified Poly(p-aminophenol) Film GCE}

Prior to modification, GCE was activated by polishing with different grades of $\mathrm{Al}_{2} \mathrm{O}_{3}$ slurry (0.05-3 micron) on a synthetic cloth, and then rinsed with pure water and ultrasonicated in ultrapure water and ethanol for $3 \mathrm{~min}$, successively. The PAP film was prepared according to previous studies [50]. The electrochemical polymerization of $p$-aminophenol was carried out in $5 \mathrm{mmol} \mathrm{L}^{-1} \mathrm{SDS}$ and $5 \mathrm{mmol} \mathrm{L}^{-1} \quad p$-aminophenol containing $0.5 \mathrm{~mol} \mathrm{~L}^{-1}$ $\mathrm{HClO}_{4}$ solution by cycling the potential from -0.5 to $2.0 \mathrm{~V}$ versus $\mathrm{Ag} / \mathrm{AgCl}$ (sat. $\mathrm{KCl}$ ) with scan rate of $100 \mathrm{mV} \mathrm{s}^{-1}$. The obtained electrode was ready for use after the final wash with ultrapure water and denoted as PAP/GCE.

Ag nanoparticles were deposited on the PAP/GCE using $\mathrm{CV}$ according to our previous study [43]. Briefly, the prepared PAP/GCE electrode was immersed in $1 \mathrm{mmol} \mathrm{L}^{-1} \mathrm{AgNO}_{3}$ and $0.1 \mathrm{~mol} \mathrm{~L}^{-1} \mathrm{HNO}_{3}$ solution. The potential was scanned between 0.3 and $-0.9 \mathrm{~V}$ by consecutive CVs with $50 \mathrm{mV} \mathrm{s}^{-1}$ scan rate for 10 cycles. The obtained metal nanoparticle-modified poly ( $p$-aminophenol) film electrodes were ready to use after the final wash with ultrapure water and denoted as Ag/PAP/GCE. Deposition of gold nanoparticles on Ag/PAP/GCE was carried out in $\mathrm{HAuCl}_{4}$ and $0.1 \mathrm{~mol} \mathrm{~L}^{-1} \mathrm{HCl}$ solution in the potential range between 0.1 to $-0.9 \mathrm{~V}$ with $50 \mathrm{mV} \mathrm{s}^{-1}$ scan rate for 10 cycles. The obtained bimetallic-modified electrode was ready to use after the final wash with ultrapure water and denoted as $\mathrm{Au}-\mathrm{Ag} / \mathrm{PAP} / \mathrm{GCE}$.

\section{Results and Discussion}

\subsection{Characterization of Electrodes}

The surface morphology of the bare GCE and modified electrodes were characterized by SEM and TEM. As it is seen in Fig. 1a, porous PAP film appears and shows almost homogenous distribution on the GCE surface which is obviously different from GCE image. On the PAP surface Ag nanoparticles with an average size of $80 \mathrm{~nm}$ are formed by cyclic voltammetry from SEM image of Ag/PAP/GCE (Fig. 1b). The particles were distributed uniformly on the PAP/GC working electrode. Figure 1c shows the SEM image of the PAP/GCE surface with Au-Ag bimentallic nanoparticles. As can be seen, the bimetallic nanoparticles are regularly distributed on the surface after consecutive deposition of $\mathrm{Au}$ and $\mathrm{Ag}$ on PAP/GCE. The nanoparticles have round shape with an average size of $90 \mathrm{~nm}$. The presence of Au and Ag on PAP surface was confirmed by EDX spectroscopy analysis (Fig. 1d). The corresponding EDX analysis for the selected arrow point and square area of SEM are shown in Fig. 1c. The weight percentage of elements found in these areas were $33.07 \%$ for $\mathrm{Au}$ and $4.88 \%$ for Ag (Fig. 1d). The size and spherical morphology of $\mathrm{Au}-\mathrm{Ag}$ bimentallic nanoparticles on the polymer substrate were also observed by TEM characterizations (Fig. 1e-h). At smaller magnifications, one can see the particles are well separated and the size is in the range of 20-50 nm (Fig. 1e, f). From the high-resolution TEM (HRTEM) images, the Au-Ag particles are substantially uniform, indicating that electron density within the volume of the particle is homogeneous (Fig. 1g, h). The data are in supportive agreement with previous reports [51, 52].

In order to characterize the chemical composition of the $\mathrm{Au}-\mathrm{Ag} / \mathrm{PAP}-$ modified glassy carbon electrode, Au $4 f$ and Ag3d photoemission core-level spectra were studied. Figure 2a, $\mathrm{b}$ shows the comparative core-level spectra for $\mathrm{Au} /$ PAP/GCE versus $\mathrm{Au}-\mathrm{Ag} / \mathrm{PAP} / \mathrm{GCE}$ and $\mathrm{Ag} / \mathrm{PAP} / \mathrm{GCE}$ versus $\mathrm{Au}-\mathrm{Ag} / \mathrm{PAP} / \mathrm{GCE}$, respectively. The dashed lines indicate the positions of the bulk metal bands. The Au4f spectrum resolves into two spin-orbit components $\left(\mathrm{Au} 4 f_{7 / 2}\right.$ and $\left.4 f_{5 / 2}\right)$ on $\mathrm{Au} / \mathrm{PAP}$ and $\mathrm{Au}-\mathrm{Ag} / \mathrm{PAP}$ electrodes (Fig. 2a). The peaks of $A u 4 f_{7 / 2}$ are observed at 84.68 and $84.1 \mathrm{eV}$ on $\mathrm{Au} / \mathrm{PAP}$ electrodes, whereas peaks of Au4 $f_{5 / 2}$ are observed at 88.31 and $87.85 \mathrm{eV}$ on $\mathrm{Au}-\mathrm{Ag} / \mathrm{PAP}$, respectively. $\mathrm{Au} 4 f$ peaks at $\mathrm{Au}-\mathrm{Ag}$ bimetallic surface are shifted towards lower binding energy (BE) by $\sim 0.6 \mathrm{eV}$ relatively to the bulk Au. The doublets are corresponding to the metallic $\mathrm{Au}$ [53]. The Ag3d signal of both Ag/PAP and $\mathrm{Au}-\mathrm{Ag} / \mathrm{PAP}$ electrode shows two peaks due to spine orbital splitting of the $3 d_{5 / 2}$ and $3 d_{3 / 2}$ states, as displayed in Fig. 2b. One of the intense doublet peaks, $\operatorname{Ag} 3 d_{5 / 2}$, were 

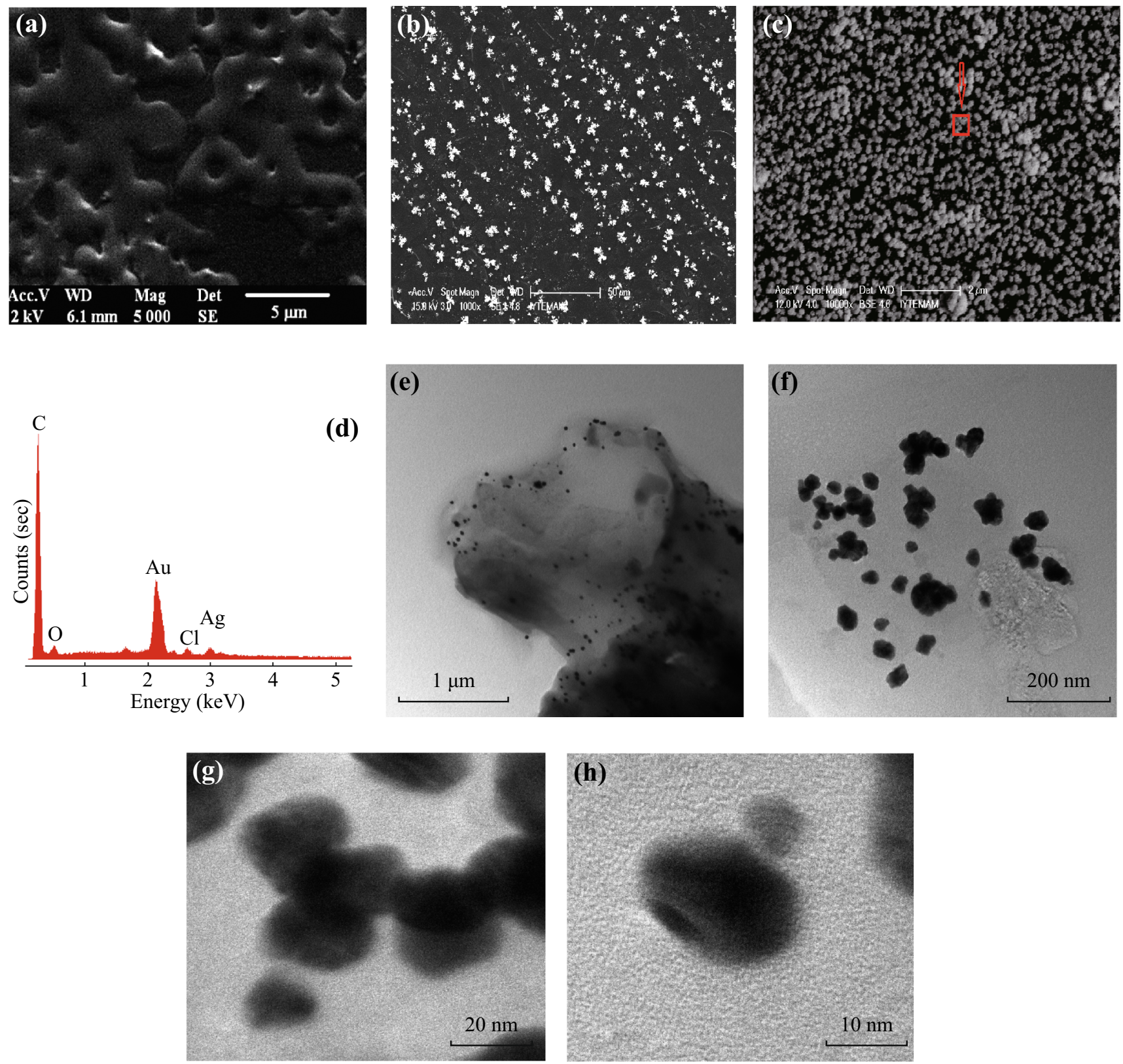

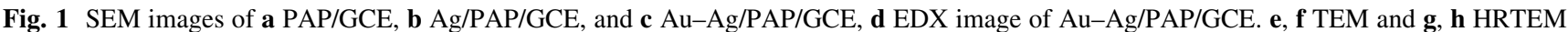
images of $\mathrm{Au}-\mathrm{Ag}$ bimentallic nanoparticles on PAP/GCE film surface

observed at 368.2 and $368.14 \mathrm{eV}$, and the other $\mathrm{Ag} 3 d_{3 / 2}$ peaks were observed at 374.3 and $374.15 \mathrm{eV}$ on $\mathrm{Ag} / \mathrm{PAP}$ and $\mathrm{Au}-\mathrm{Ag} / \mathrm{PAP}$, respectively. The results could be attributed to the metallic Ag [54]. The evaluation of the $\mathrm{Ag} 3 d$ spectra of $\mathrm{Au}-\mathrm{Ag}$ bimetallic surface reveals higher energy BE shift of ca. $0.1 \mathrm{eV}$ related to the bulk metal value. The shifting of binding energy values indicates an alloyed formation with atomic level by mixing of $\mathrm{Au}$ and $\mathrm{Ag}$. The 1.3:1.0 ratio of $\mathrm{Au}$ and $\mathrm{Ag}$ in $\mathrm{Au}-\mathrm{Ag} / \mathrm{PAP}$ electrode surface can be extracted from XPS data of $56.6 \%$ for $\mathrm{Au}$ and $43.4 \%$ for $\mathrm{Ag}$ atomic content.
Figure $2 c$ shows EIS results of bare GCE, PAP/GCE, Au/ PAP/GCE, Ag/PAP/GCE, and Au-Ag/PAP/GCE in the presence of $5 \mathrm{mmol} \mathrm{L}^{-1}\left[\mathrm{Fe}(\mathrm{CN})_{6}\right]^{3-/ 4-}$ containing $0.1 \mathrm{~mol} \mathrm{~L}^{-1} \mathrm{KCl}$ solution at frequency range from 0.5 to $50.000 \mathrm{~Hz}$. It can be seen that all electrodes represent a semi-circular and linear portion. The semi-circle corresponds to the charge transfer process through the GCE and polymer films at high frequencies, whereas the second one is due to the diffusion process in the low frequencies. The diameter of the semi-circle represents the magnitude of electron-transfer resistance at the electrode surface. The EIS 

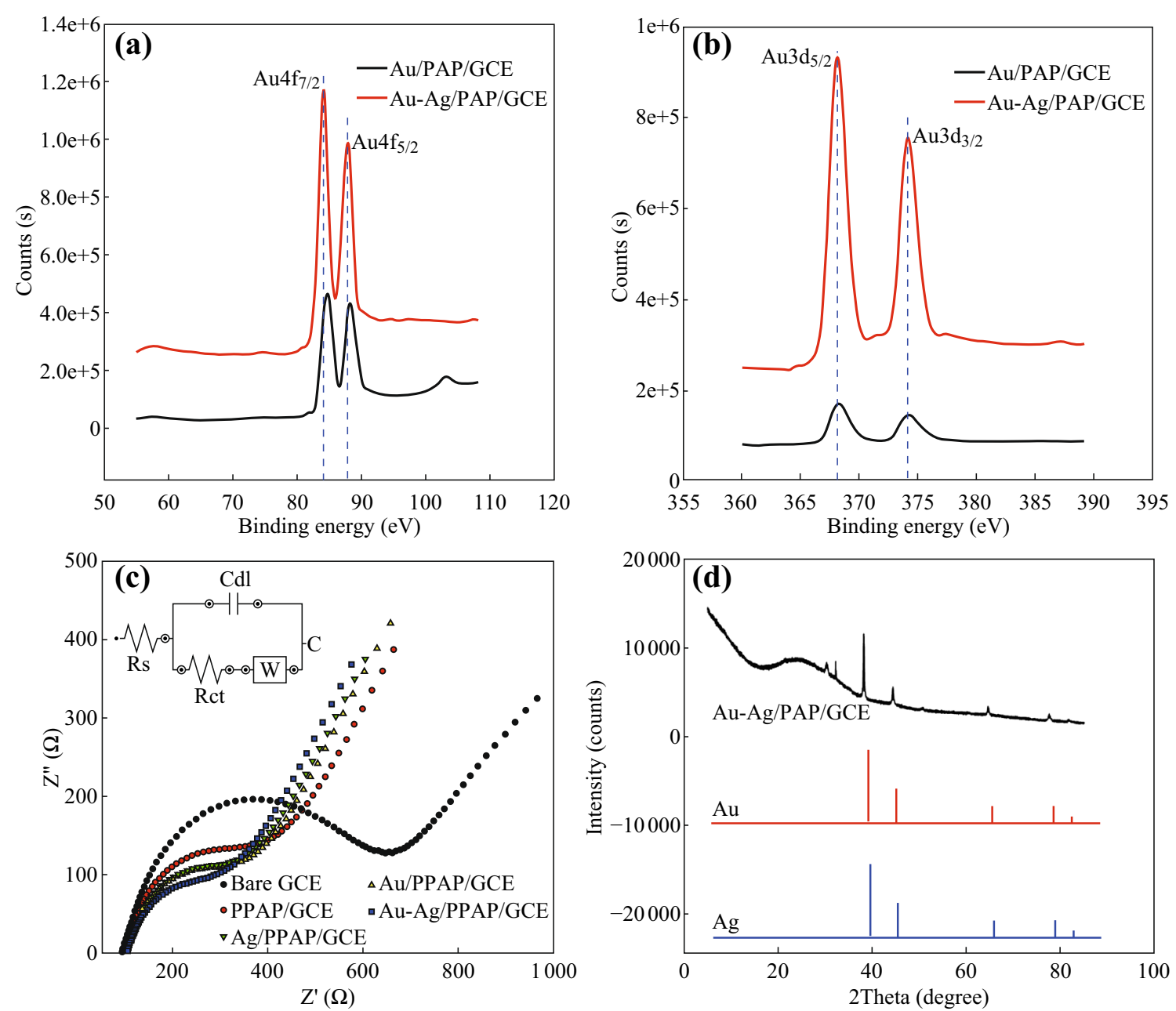

Fig. 2 XPS spectra of a Au/PAP/GCE versus Au-Ag/PAP/GCE, b Ag/PAP/GCE versus Au-Ag/PAP/GCE. c The Nyquist plots of the bare GCE, PAP/GCE, Ag/PAP/GCE, Au/PAP/GCE, and Au-Ag/PAP/GCE. d XRD pattern of the Au-Ag/PAP/GCE electrode. The standard patterns of pure $\mathrm{Au}$ (ICSD 98-006-4701) and Ag (ICSD 98-006-4997) are attached for comparison

data were fitted with an $R_{\mathrm{S}}\left(C\left(R_{\mathrm{ct}} W\right)\right)$ equivalent circuit as given in Fig. 2c inset. This equivalent circuit consists of ohmic resistance $\left(R_{\mathrm{s}}\right)$ of electrolyte solution, the doublelayer capacitance $(\mathrm{Cdl})$, and electron-transfer resistance $\left(R_{\mathrm{ct}}\right)$ resulting from the diffusion of ions from bulk of the electrolyte to the interface and Warburg impedance $(W)$. Large semi-circle as $428 \Omega$ of $R_{\mathrm{ct}}$ value was obtained for bare GCE, indicating that there is a high electron-transfer resistance. However, after PAP film modification, a smaller semi-circle was obtained which meant low electron-transfer resistance. $R_{\mathrm{ct}}$ value obtained for PAP/GCE is $194 \Omega$ which is higher than the metal nanoparticle-modified polymer film electrodes. The $R_{\mathrm{ct}}$ values of $\mathrm{Au} / \mathrm{PAP} / \mathrm{GC}$ and $\mathrm{Ag} / \mathrm{PAP} / \mathrm{GC}$ electrodes were found to be 157 and $154 \Omega$, respectively. The $R_{\mathrm{ct}}$ value of $\mathrm{Au}-\mathrm{Ag}$ bimetallic surface is obviously smaller than other modified electrodes $(126 \Omega)$. This phenomenon proves the excellent electroconductibility of $\mathrm{Ag}-$
$\mathrm{Au}$ bimetallic surface. Moreover, these results show that $\mathrm{Au}-\mathrm{Ag} / \mathrm{PAP}$ film is successfully formed on the GCE surface.

The crystal structure of the $\mathrm{Au}-\mathrm{Ag} / \mathrm{PAP}-$ modified glassy carbon electrodes was also investigated and their XRD patterns are shown in Fig. 2d. As can be seen, five characteristic peaks of $\{111\},\{200\},\{220\},\{311\}$, and $\{222\}$ were, respectively, located at $38.28,44.34,64.54,77.52$, and 81.72, indicating an $f c c \mathrm{Au}-\mathrm{Ag}$ alloy structure $[55,56]$. Moreover, the XRD patterns of $\mathrm{Au}$ and $\mathrm{Ag}$ are completely overlapped since the lattice constants of $\mathrm{Au}(0.4080 \mathrm{~nm})$ and $\mathrm{Ag}(0.4086 \mathrm{~nm})$ are almost similar. Therefore, the $\mathrm{Au}-$ $\mathrm{Ag}$ alloy cannot be distinguished from the XRD powder patterns as monometallic phases [57]. Based on the experimental observations, the peak corresponding to the $\{111\}$ plane is more intense than those to other planes, indicating that the $\{111\}$ plane has the predominant orientation. It can be concluded that $\mathrm{Au}-\mathrm{Ag}$ nanobimetallic 
structure has been successfully prepared on $\operatorname{poly}(p$ aminophenol) surface by a simple electrode position using CV technique.

\subsection{Electrochemical Behavior of Ammonia Borane on Different Electrodes}

The electrochemical behaviors of various electrodes, such as bare GCE, PAP/GCE, Au disk electrode, Ag/PAP/GCE, $\mathrm{Au} / \mathrm{PAP} / \mathrm{GCE}, \mathrm{Ag}-\mathrm{Au} / \mathrm{PAP} / \mathrm{GCE}$ (firstly $\mathrm{Au}$ deposition, and then $\mathrm{Ag}$ deposition on $\mathrm{Au} / \mathrm{PAP} / \mathrm{GCE}$ ), and $\mathrm{Au}-\mathrm{Ag} /$ PAP/GCE (firstly Ag deposition, and then Au deposition on $\mathrm{Ag} / \mathrm{PAP} / \mathrm{GCE}$ ) towards the $\mathrm{AB}$ oxidation were investigated in $2.0 \mathrm{M} \mathrm{NaOH}$ using $\mathrm{CV}$ technique. As can be seen from Fig. 3a, there isn't any oxidation or reduction peak in either
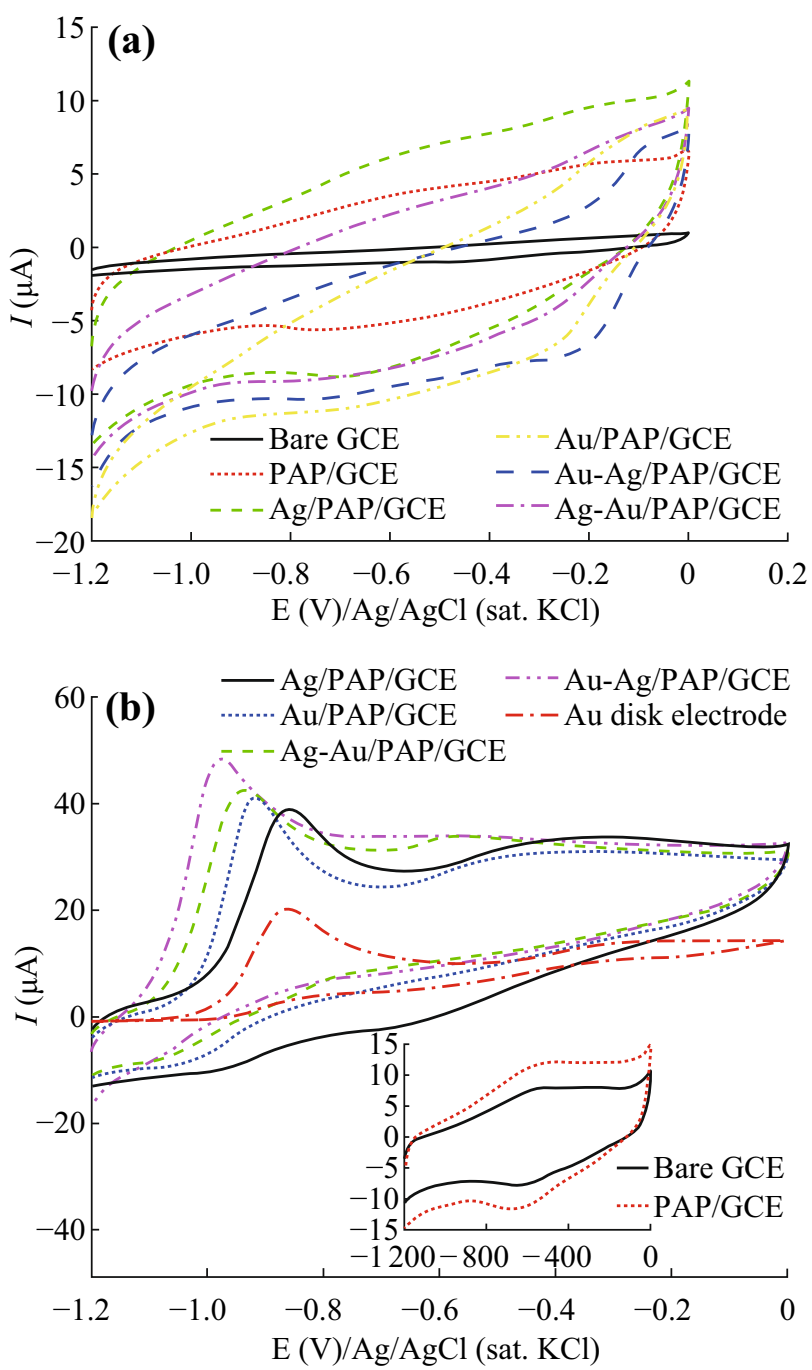

Fig. 3 Cyclic voltammograms for bare GCE, PAP/GCE, Ag/PAP/ GCE, Au/PAP/GCE, Au-Ag/PAP/GCE, and Ag-Au/PAP/GCE in $2.0 \mathrm{~mol} \mathrm{~L}-1 \mathrm{NaOH}$ a absence of $\mathrm{AB}$ and $\mathbf{b}$ presence of $1.0 \mathrm{mmol} \mathrm{L}^{-1}$ $\mathrm{AB}$, scan rate: $50 \mathrm{mV} \mathrm{s}^{-1}$ anodic or cathodic current-potential scan in the absence of $\mathrm{AB}$ at modified and bare electrodes. Modification of GCE with poly( $p$-aminophenol), Au and Ag nanoparticles resulted in the increment on background currents.

Figure $3 \mathrm{~b}$ shows the cyclic voltammograms of the bare GCE, Au disk, and all modified electrodes in the $2.0 \mathrm{M}$ $\mathrm{NaOH}$ solution containing $1.0 \mathrm{mM}$ AB. Electrochemical behavior of $\mathrm{AB}$ on bare GCE and PAP/GC electrodes are given in the inset of Fig. 3b, in which there is no oxidation or reduction peaks observed in the presence of $\mathrm{AB}$. This result shows that bare GCE and PAP/GCE surface have no catalytic affect towards $\mathrm{AB}$ electrooxidation. On the contrary, well-defined oxidation peaks were observed at ca. $-0.863 \mathrm{~V}$ on $\mathrm{Au}$ disk, $-0.917 \mathrm{~V}$ on $\mathrm{Au}_{10 \text { cyc }} / \mathrm{PAP}$, $-0.865 \mathrm{~V}$ on $\mathrm{Ag}_{10 \mathrm{cyc}} / \mathrm{PAP},-0.943 \mathrm{~V}$ on $\mathrm{Ag}_{10 \mathrm{cyc}}-\mathrm{Au}_{10 \mathrm{cyc}} /$ $\mathrm{PAP}$, and $-0.978 \mathrm{~V}$ on $\mathrm{Au}_{10 \mathrm{cyc}}-\mathrm{Ag}_{10 \mathrm{cyc}} / \mathrm{PAP}$-modified GC electrodes for $1.0 \mathrm{mmol} \mathrm{L}^{-1} \mathrm{AB}$ in $2.0 \mathrm{~mol} \mathrm{~L}^{-1} \mathrm{NaOH}$ solution. In addition, another small anodic peak as a shoulder was observed at about $-0.40 \mathrm{~V}$ on these electrodes during the anodic way potential scans. Both oxidation peaks are related with the $\mathrm{AB}$ species that agree with the published work of Au nanoporous gold catalyst [16] and microelectrodes [17]. The first peak located at more negative potential may be assigned to the electrooxidation of $\mathrm{BH}_{3} \mathrm{OH}^{-}$produced by chemical dissociation of $\mathrm{BH}_{3}$ from $\mathrm{AB}$ which reacts with $\mathrm{OH}^{-}$. The second small anodic peak located at more positive potential that can be associated with oxidation product of $\mathrm{BH}_{3} \mathrm{OH}^{-}$, without the implication of $\mathrm{H}_{2}$ electrooxidation.

The above $\mathrm{CV}$ results show that the $\mathrm{Au}-\mathrm{Ag}$ nanoalloy exhibits much higher catalytic activity for the electrocatalytic oxidation of $\mathrm{AB}$ in terms of peak potential and peak current in comparison with other modified electrodes. The $\mathrm{AB}$ oxidation potential is more negative on $\mathrm{Au}-\mathrm{Ag}$ surface than those observed on Au/PAP and Ag/PAP surfaces,

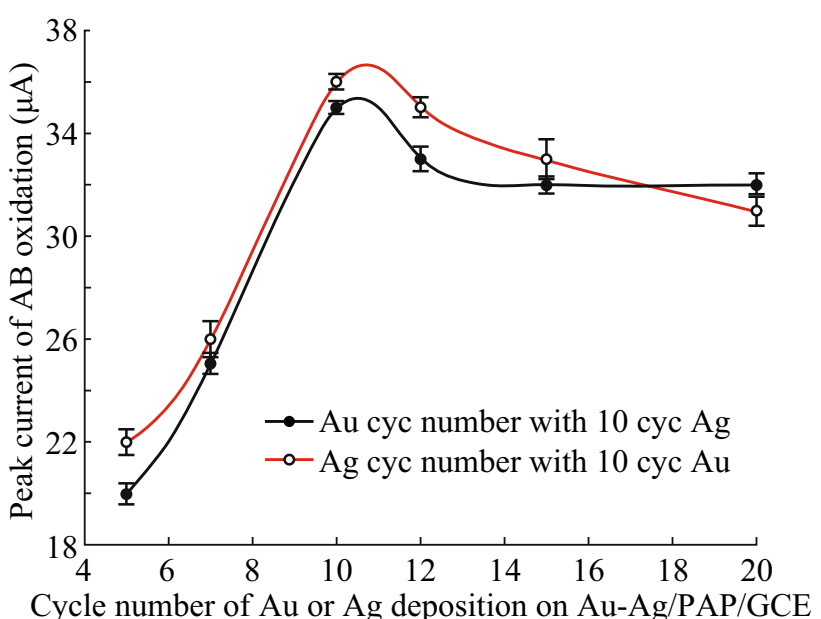

Fig. 4 Dependence of $\mathrm{Ag}$ and $\mathrm{Au}$ modification cycle number on oxidation peak current of $1 \mathrm{mmol} \mathrm{L}^{-1} \mathrm{AB}$ in $2 \mathrm{~mol} \mathrm{~L}^{-1} \mathrm{NaOH}$ 
respectively. The shifting of oxidation potential to more negative potentials could be attributed to the existence of bimetallic $\mathrm{Au}-\mathrm{Ag}$ alloy particles on the polymer support that enhance the electrocatalytic oxidation kinetics of $\mathrm{AB}$.

When compared the present results with reported papers [16-18], the electrochemical oxidation of $\mathrm{AB}$ was monitored at more negative potential on $\mathrm{Au}-\mathrm{Ag}$ bimetallic surface than the published papers. The higher catalytic activity of $\mathrm{Au}-\mathrm{Ag} / \mathrm{PAP} / \mathrm{GCE}$ can be explained by the synergetic effect of alloy bimetallic particles supported by XPS, XRD, and TEM studies.

To prepare $\mathrm{Au}-\mathrm{Ag} / \mathrm{PAP} / \mathrm{GC}$ electrode with improved electrocatalytic activity towards $\mathrm{AB}$ oxidation, a series of parameters were optimized, such as $\mathrm{NaOH}$ concentration, $p$-aminophenol concentration, and polymerization cycle number. After optimization studies, the optimum parameters were evaluated as follows: $2.0 \mathrm{M} \mathrm{NaOH}, 5.0 \mathrm{mM}$ aminophenol concentration, and 35 cycles for
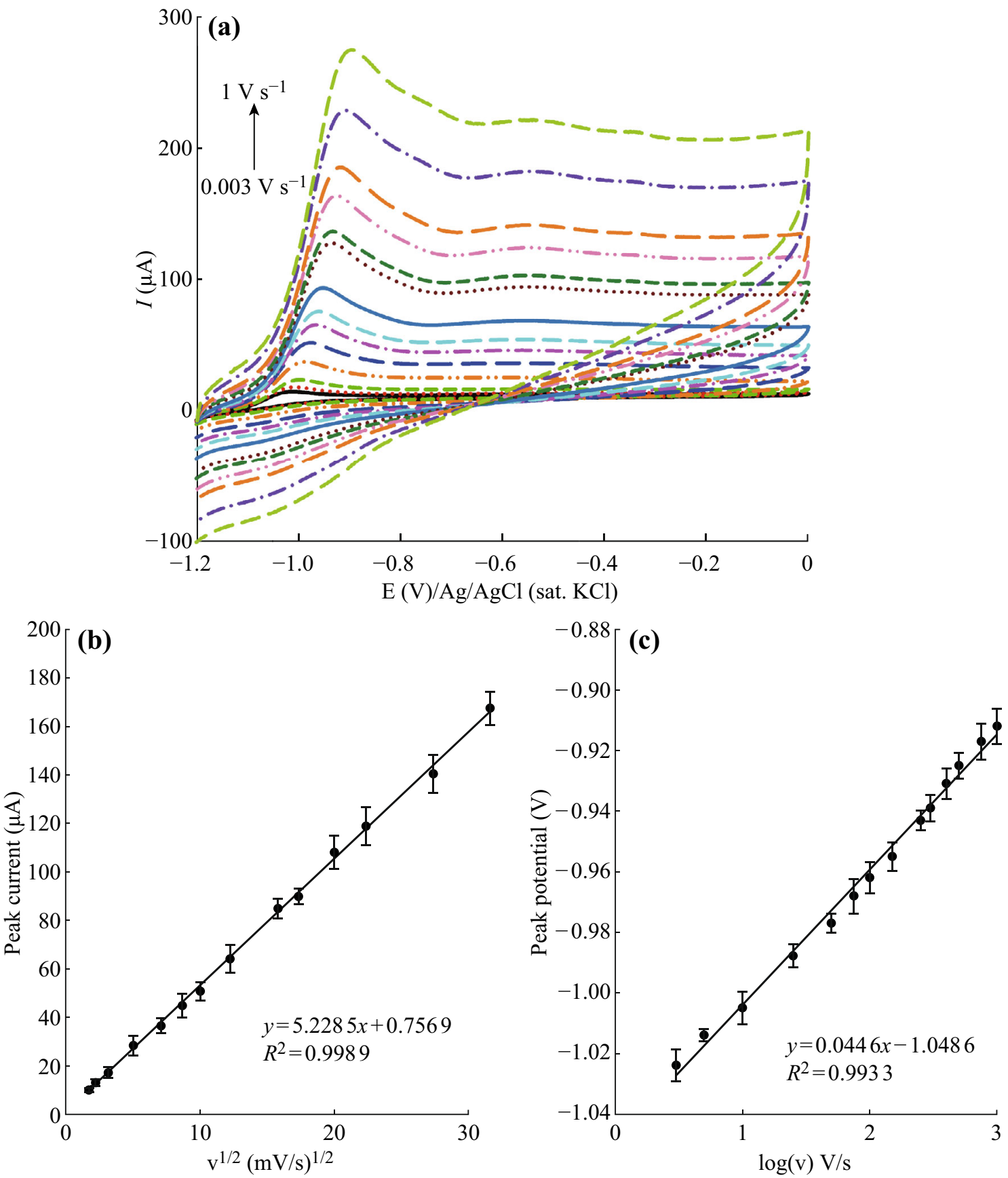

Fig. 5 a CVs of $\mathrm{Au}-\mathrm{Ag} / \mathrm{PAP} / \mathrm{GC}$ electrode in the presence of $1.0 \mathrm{mmol} \mathrm{L}^{-1} \mathrm{AB}+2 \mathrm{~mol} \mathrm{~L}^{-1} \mathrm{NaOH}$ with different scan rates of $0.003,0.005$, $0.010,0.025,0.050,0.075,0.100,0.150,0.250,0.300,0.400,0.500,0.750$, and $1.000 \mathrm{~V} \mathrm{~s}^{-1}$. b $E_{\mathrm{p}}$ versus $\log v$ plot. c $I_{\mathrm{p}}$ versus $v^{1 / 2}$ plot 
polymerization. The PAP/GC electrodes were prepared with different coverages by changing the cycle numbers of $\mathrm{Au}$ and Ag deposition (Fig. 4) in order to obtain the best composition of $\mathrm{Au}-\mathrm{Ag}$ on PAP surface for $\mathrm{AB}$ oxidation. The overall results prove that bimetallic nanoparticlemodified PAP/GC electrodes offer a satisfactory enhancement in peak characteristics of $\mathrm{AB}$ oxidation. The desirable change in oxidation peak current was observed for 10 cycles of Ag deposition followed by 10 cycles of $\mathrm{Au}$ deposition on PAP/GCE surface.

The effect of scan rate on the $\mathrm{CV}$ behavior of $\mathrm{Au}-\mathrm{Ag} /$ $\mathrm{PAP} / \mathrm{GC}$ electrode in the presence of $1.0 \mathrm{mM} \mathrm{AB}$ is shown in Fig. 5a. Cyclic voltammograms were obtained from potential scan between -1.2 to $0.0 \mathrm{~V}$ with different scan rates of $3-1000 \mathrm{mV} \mathrm{s}^{-1}$. The peak current increases linearly with the square root of scan rate over the range of 3-1000 $\mathrm{mV} \mathrm{s}^{-1}$ (Fig. 5b). The linear regression equation was found as $i_{\mathrm{p}}(\mu \mathrm{A})=3.076 v^{1 / 2}\left(\left(\mathrm{mV} \mathrm{s}^{-1}\right)^{1 / 2}\right)+1.6251$ with a correlation coefficient of $R^{2}=0.9994$. According to these results, anodic peak current was controlled by the mass diffusion indicating a diffusion-controlled process. A plot of oxidation peak potential $\left(E_{p}\right)$ versus $\log v$ for $\mathrm{Au}-$ $\mathrm{Ag} / \mathrm{PAP} / \mathrm{GCE}$ is given in Fig. 5c. A linear relation between peak potential and logarithm of scan rate for $\mathrm{AB}$ oxidation peak indicates that there is an irreversible electrode process on $\mathrm{Au}-\mathrm{Ag} / \mathrm{PAP} / \mathrm{GCE}$ surface. This is coherent with the linearity value that was calculated from the Laviron equation $[58,59]$.

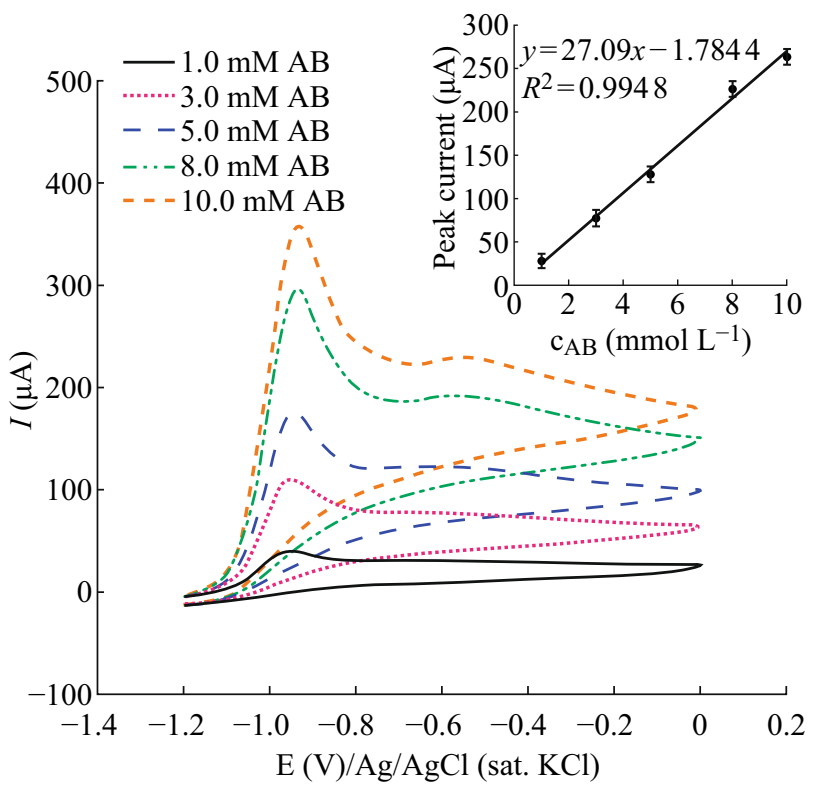

Fig. 6 Cyclic voltammograms of $\mathrm{Au}-\mathrm{Ag} / \mathrm{PAP} / \mathrm{GC}$ electrode in $2.0 \mathrm{~mol} \mathrm{~L}^{-1} \mathrm{NaOH}$ presence with different $\mathrm{AB}$ concentrations where the scan rate is $0.050 \mathrm{~V} \mathrm{~s}^{-1}$. Inset Anodic peak current vs. $\mathrm{AB}$ concentration for the $\mathrm{Au}-\mathrm{Ag} / \mathrm{PAP} / \mathrm{GC}$ electrode
The catalytic activity of $\mathrm{Au}-\mathrm{Ag} / \mathrm{PAP} / \mathrm{GCE}$ was also studied in the concentration range between 1.0 and $10 \mathrm{mM}$ of $\mathrm{AB}$ (Fig. 6). However, the oxidation peak potential of $\mathrm{AB}$ shifted slightly to more positive values with increasing concentrations of $\mathrm{AB}$, and a linear relationship was observed between the peak current and $\mathrm{AB}$ concentration. Expectedly, for higher $\mathrm{AB}$ concentrations, it takes more time to consume all $\mathrm{AB}$ at the electrode surface where oxidation peak appears at more positive potentials. The linear dependence of peak current on $\mathrm{AB}$ concentrations indicates that $\mathrm{Au}-\mathrm{Ag} / \mathrm{PAP} / \mathrm{GC}$ electrode shows well catalytic activity in all diluted or concentrated $\mathrm{AB}$ solutions in alkaline media.

In rotating disk electrode (RDE) voltammetry, the number of electrons involved in an oxidation reaction at a
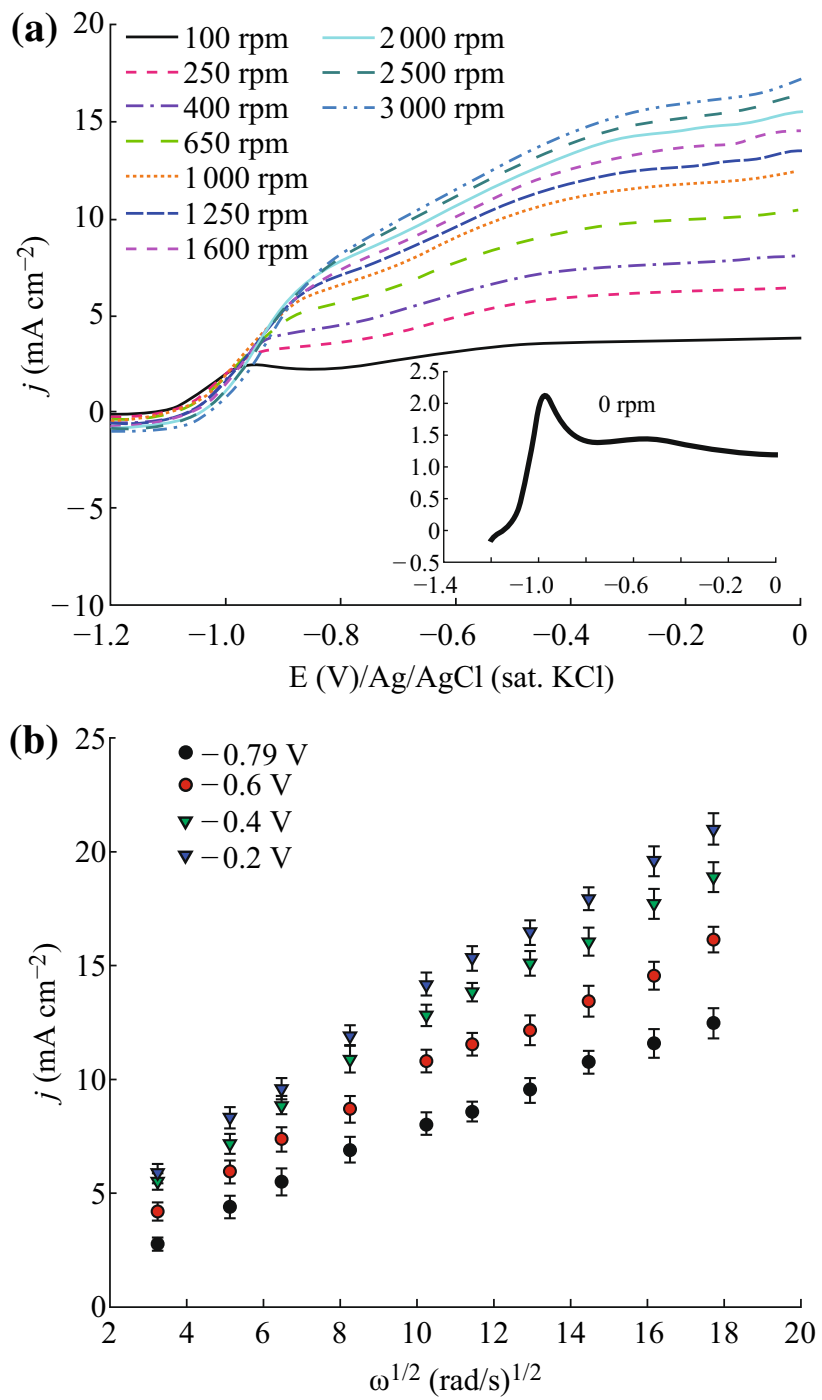

Fig. 7 a LSVs of $5.0 \mathrm{mmol} \mathrm{L}^{-1} \mathrm{AB}$ in $2.0 \mathrm{~mol} \mathrm{~L}^{-1} \mathrm{NaOH}$ at $\mathrm{Au}-$ $\mathrm{Ag} / \mathrm{PAP} / \mathrm{GCE}$ rotated between 100 and $3000 \mathrm{rpm}$ (the inset is $0 \mathrm{rpm}$ ). b Levich plots for $\mathrm{AB}$ oxidation at $\mathrm{Au}-\mathrm{Ag} / \mathrm{PAP} / \mathrm{GCE}$ under the indicated potentials taken from a 
specific potential can be obtained from the Levich equation (Eq. 3) [60], where $n$ is the number of the transferred electrons, $F$ is the faraday constant $\left(96,485 \mathrm{C} \mathrm{mol}^{-1}\right), A$ is the electrode area $\left(\mathrm{cm}^{2}\right), D$ is the diffusion coefficient $\left(\mathrm{cm}^{2} \mathrm{~s}^{-1}\right), v$ is the kinematic viscosity, and $C$ is the analyte concentration $\left(\mathrm{mol} \mathrm{cm} \mathrm{cm}^{-3}\right)$.

$i=-0.62 n F A D^{2 / 3} v^{-1 / 6} C \omega^{1 / 2}$.

In RDE experiment, $D$ value for $\mathrm{AB}$ in $2.0 \mathrm{M} \mathrm{NaOH}$ media was taken as $8.45 \times 10^{-6} \mathrm{~cm}^{2} \mathrm{~s}^{-1}$, which was determined by Nagle and Rohan [17]. The kinematic viscosity $(v)$ of solution was taken as $1.216 \times 10^{-2} \mathrm{~cm}^{2} \mathrm{~s}^{-1}$ determined with Oswald viscosimeter at room temperature. A representative linear sweep voltammogram (LSV) of $5.0 \mathrm{mmol} \mathrm{L}^{-1} \mathrm{AB}$ at $\mathrm{Au}-\mathrm{Ag}$ / PAP/GCE is shown in the inset of Fig. 7a. In LSV study, AB oxidation peak was observed at $-0.867 \mathrm{~V}$ on $\mathrm{Au}-\mathrm{Ag} / \mathrm{PAP} /$ GCE. In order to determine the number of electrons during AB oxidation, LSVs were obtained at Au-Ag/PAP/GCE with different rotation speeds (100-3000 rpm) (Fig. 7a). The oxidation currents increased with rotation rate indicate contribution of mass-transport control regime, at least within region of higher potentials. The curves also show the classical limiting current at higher potentials [61]. The large shift of halfwave potential to more positive values was observed as rotation speed of increased electrode. It has also been reported that $\mathrm{Au}$ indicates an irreversible reaction [62]. As expected, the complicated multielectron reactions involve formation of many intermediates on Au surface [63, 64]. The Levich graph represents the relationship between current density $(j)$ and square root of rotation rate $\left(\omega^{1 / 2}\right)$ which draws various potentials as shown in Fig. 7b. According to the slope, the number of electrons transferred during the $\mathrm{AB}$ oxidation at $\mathrm{Au}-\mathrm{Ag} / \mathrm{PAP} / \mathrm{GCE}$ is calculated to be 5.7 for high potential $(-0.2 \mathrm{~V})$. This value is close to the theoretical value of 6 , as expected. The numbers of electrons transferred during the $\mathrm{AB}$ oxidation at Au disk electrode, Au/PAP/GCE, Ag/PAP/GCE, and $\mathrm{Ag}-\mathrm{Au} / \mathrm{PAP} / \mathrm{GCE}$ were also calculated as 5.9, 6.0, 4.5, and 5.0, respectively.

The chronoamperometry measurements reveal more information about electrocatalytic activity and stability of the catalysts. The chronoamperometry responses of $\mathrm{Au}$ disk, Au/PAP, Ag/PAP, Ag-Au/PAP, and Au-Ag/PAPmodified GC electrodes in the presence of $8 \mathrm{mmol} \mathrm{L}^{-1} \mathrm{AB}$ for $300 \mathrm{~s}$ are shown in Fig. 8. The current values of all modified electrodes decrease rapidly in the initial stage, and then reach steady-state characteristics. The highest steady-state peak current obtained at $\mathrm{Au}-\mathrm{Ag}$ electrode corresponds to the high catalytic activity of this electrode for $\mathrm{AB}$ oxidation compared to other electrodes.

In order to estimate the number of electrons exchanged (n) of $\mathrm{AB}$, the Cottrell equation was used based on chronoamperometry measurement [65]:

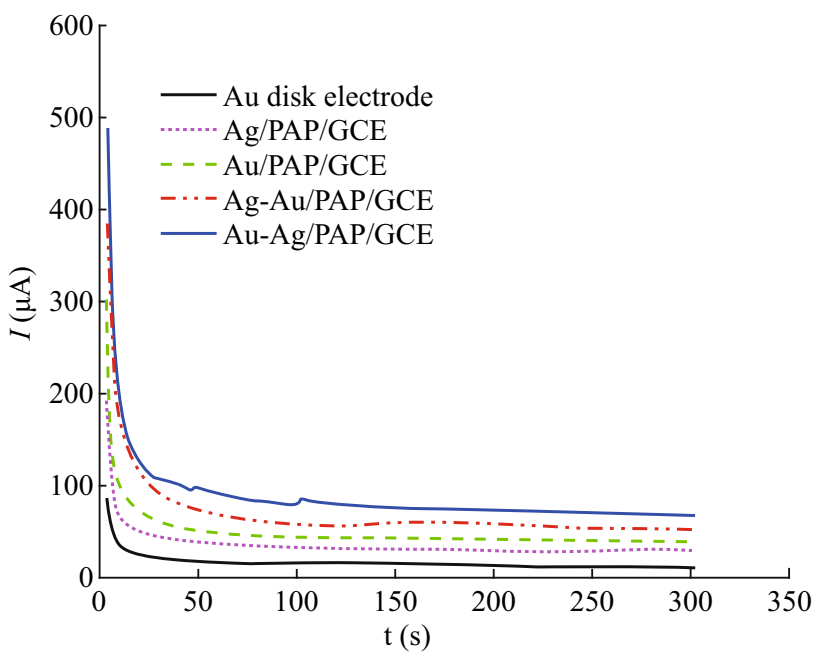

Fig. 8 Chronoamperometric curves of $8.0 \mathrm{mmol} \mathrm{L}^{-1} \mathrm{AB}$ oxidation on $\mathrm{Au}$ disk, Au/PAP/GCE, Ag/PAP/GCE, Ag-Au/PAP/GCE, and $\mathrm{Au}-\mathrm{Ag} / \mathrm{PAP} / \mathrm{GCE}$ electrodes in $2.0 \mathrm{~mol} \mathrm{~L}^{-1} \mathrm{NaOH}$

$i=\frac{n F A C D^{1 / 2}}{\pi^{1 / 2} t^{1 / 2}}$.

Here $i$ is the current density of electrodes $\left(\mathrm{mA} \mathrm{cm}^{-2}\right)$, $F$ is the faradaic constant $\left(96,485 \mathrm{C} \mathrm{mol}^{-1}\right), A$ is the electrode area $\left(\mathrm{cm}^{2}\right), C$ is the bulk borohydride concentration $\left(\mathrm{mol} \mathrm{cm}{ }^{-3}\right)$, and $D$ is the diffusion coefficient $\left(\mathrm{cm}^{2} \mathrm{~s}^{-1}\right)$ taken as $8.45 \times 10^{-6} \mathrm{~cm}^{2} \mathrm{~s}^{-1}$. The calculated $n$ value from $i$ versus $t^{-1 / 2}$ graph for $\mathrm{Au}$ disk electrode, $\mathrm{Au} / \mathrm{PAP}, \mathrm{Ag} / \mathrm{PAP}, \mathrm{Ag}-\mathrm{Au} / \mathrm{PAP}$, and $\mathrm{Au}-\mathrm{Ag} / \mathrm{PAP}$ electrodes are 5.96, 6.04, 4.5, 5.3, and 5.8, respectively. These values are coherent with the electrons calculated with RDE.

\section{Conclusion}

In the present study, well-dispersed Au/PAP, Ag/PAP, and $\mathrm{Au}-\mathrm{Ag}$ bimentallic nanoparticles were successfully synthesized on polymer PAP/GCE films by electrochemical reduction process with $\mathrm{CV}$ technique. An average diameter of $\mathrm{Au}, \mathrm{Ag}$, and $\mathrm{Au}-\mathrm{Ag}$ nanoparticles on the polymer films are 150,80 , and $85 \mathrm{~nm}$, respectively, while the $\mathrm{Au}-\mathrm{Ag}$ bimetallic nanoparticles were in the range of $20-50 \mathrm{~nm}$. $\mathrm{Au}-\mathrm{Ag} / \mathrm{PAP} / \mathrm{GCE}$ exhibits relatively high electrocatalytic activity for $\mathrm{AB}$ oxidation in terms of both oxidation peak potential and peak current. The highest catalytic activity may be attributed to the synergistic effect, unique structure, and homogenous dispersion of $\mathrm{Au}-\mathrm{Ag}$ bimentallic nanoparticles on PAP/GCE surface. Additionally, Au-Ag/ PAP/GCE exhibits high electrocatalytic activity for $\mathrm{AB}$. 
This will be attractive to anode materials for ammonia borane fuel cells under alkaline conditions.

Acknowledgments This work was supported by the Scientific and Technical Research Council of Turkey (TUBITAK) with $110 \mathrm{~T} 806$ project number, EBILTEM with BIL-012 project number, and Ege University Research Funds (BAP project, 10 FEN/075). The author thanks the Associate Prof. Dr. Armağan Kınay for his careful reading of the manuscript.

Open Access This article is distributed under the terms of the Creative Commons Attribution 4.0 International License (http://crea tivecommons.org/licenses/by/4.0/), which permits unrestricted use, distribution, and reproduction in any medium, provided you give appropriate credit to the original author(s) and the source, provide a link to the Creative Commons license, and indicate if changes were made.

\section{References}

1. W.L. Henrietta, G.S. McGrady, Non-hydride systems of the main group elements as hydrogen storage materials. Coordin. Chem. Rev. 251(7), 925-935 (2007). doi:10.1016/j.ccr.2006.09.009

2. Ö. Metin, E. Kayhan, S. Özkar, J.J. Schneider, Palladium nanoparticles supported on chemically derived graphene: an efficient and reusable catalyst for the dehydrogenation of ammonia borane. Int. J. Hydrogen Energy 37(10), 8161-8169 (2012). doi:10.1016/j.ijhydene.2012.02.128

3. R. Chiriac, F. Toche, U.B. Demirci, P. Miele, Ammonia borane thermolytic decomposition in the presence of metal (II) chlorides. Int. J. Hydrogen Energy 37(8), 6749-6755 (2012). doi:10.1016/j. ijhydene.2012.01.037

4. G.P. Rachiero, U.B. Demirci, P. Miele, Bimetallic RuCo and $\mathrm{RuCu}$ catalysts supported on $\gamma-\mathrm{Al}_{2} \mathrm{O}_{3}$. A comparative study of their activity in hydrolysis of ammonia-borane. Int. J. Hydrogen Energy 36(12), 7051-7065 (2011). doi:10.1016/j.ijhydene.2011. 03.009

5. J. Liao, H. Li, X. Zhang, Preparation of Ti supported Co film composed of Co nanofibers as catalyst for the hydrolysis of ammonia borane. Catal. Commun. 67, 1-5 (2015). doi:10.1016/j. catcom.2015.03.036

6. A.C. Gangal, P. Kale, R. Edla, J. Manna, P. Sharma, Study of kinetics and thermal decomposition of ammonia borane in presence of silicon nanoparticles. Int. J. Hydrogen Energy 37(8), 6741-6748 (2012). doi:10.1016/j.ijhydene.2012.01.017

7. M.B.M. Conchaa, M. Chateneta, F.H.B. Limab, E.A. TicianelliI, In situ Fourier transform infrared spectroscopy and on-line differential electrochemical mass spectrometry study of the $\mathrm{NH}_{3-}$ $\mathrm{BH}_{3}$ oxidation reaction on gold electrodes. Electrochim. Acta 89, 607-615 (2013). doi:10.1016/j.electacta.2012.11.027

8. M. Rakap, S. Özkar, Hydrogen generation from the hydrolysis of ammonia-borane using intra zeolite cobalt $(0)$ nanoclusters catalyst. Int. J. Hydrogen Energy 35(8), 3341-3346 (2010). doi:10. 1016/j.ijhydene.2010.01.138

9. U.B. Demirci, P. Miele, Hydrolysis of solid ammonia borane. J. Power Sources 195(13), 4030-4035 (2010). doi:10.1016/j. jpowsour.2010.01.002

10. M. Rakap, S. Özkar, Hydroxyapatite-supported palladium(0) nanoclusters as effective and reusable catalyst for hydrogen generation from the hydrolysis of ammonia-borane. Int. J. Hydrogen Energy 36(12), 7019-7027 (2011). doi:10.1016/j.ijhy dene.2011.03.017
11. S. Basu, A. Brockman, P. Gagare, Y. Zheng, P.V. Ramachandran, W.N. Delgass, J.P. Gore, Chemical kinetics of Ru-catalyzed ammonia borane hydrolysis. J. Power Sources 188(1), 238-243 (2009). doi:10.1016/j.jpowsour.2008.11.085

12. M. Zahmakıran, T. Ayvalı, S. Akbayrak, S. Çalışkan, D. Çelik, S. Özkar, Zeolite framework stabilized nickel(0) nanoparticles: active and long-lived catalyst for hydrogen generation from the hydrolysis of ammonia-borane and sodium borohydride. Catal. Today 170(1), 76-84 (2011). doi:10.1016/j.cattod.2010.09.022

13. X. Yang, F. Cheng, Z. Tao, J. Chen, Hydrolytic dehydrogenation of ammonia borane catalyzed by carbon supported Co core-Pt shell nanoparticles. J. Power Sources 196(5), 2785-2789 (2011). doi:10.1016/j.jpowsour.2010.09.079

14. M. Wen, S. Zhou, Q. Wu, J. Zhang, Q. Wu, C. Wang, Y. Sun, Construction of NiCo-Pt nanopolyhedron inlay-structures and their highly efficient catalysis hydrolytic dehydrogenation toward ammonia borane. J. Power Sources 232(12), 86-92 (2013). doi:10.1016/j.jpowsour.2012.12.070

15. V. Kiran, S.B. Kalidindi, B.R. Jagirdar, S. Sampath, Electrochemical oxidation of boron containing compounds on titanium carbide and its implications to direct fuel cell. Electrochim. Acta 56(28), 10493-10499 (2011). doi:10.1016/j.electacta.2011.04. 032

16. L.C. Nagle, J.F. Rohan, Nanoporous gold catalyst for direct ammonia borane fuel cells. J. Electrochem. Soc. 158(7), B772B778 (2011). doi:10.1149/1.3583637

17. L.C. Nagle, J.F. Rohan, Ammonia borane oxidation at gold microelectrodes in alkaline solutions. J. Electrochem. Soc. 153(153), C773-C776 (2006). doi:10.1149/1.2344842

18. X.B. Zhang, S. Han, J.M. Yan, H. Shioyama, N. Kuriyama, T. Kobayashi, Q. Xu, Electrochemical oxidation of ammonia borane on gold electrode. Int. J. Hydrogen Energy 34(1), 174-179 (2009). doi:10.1016/j.ijhydene.2008.09.083

19. X.B. Zhang, J.M. Yan, S. Han, H. Shioyama, Q. Xu, Magnetically recyclable Fe@Pt core-shell nanoparticles and their use as electrocatalysts for ammonia borane oxidation: the role of crystallinity of the core. J. Am. Chem. Soc. 131(8), 2778-2779 (2009). doi:10.1021/ja808830a

20. M. Mazloum-Ardakani, A. Dehghani-Firouzabadi, M.A. SheikhMohseni, A. Benvidi, B.B.F. Mirjalili, R. Zare, A self-assembled monolayer on gold nanoparticles modified electrode for simultaneous determination of isoproterenol and uric acid. Measurement 62, 88-96 (2015). doi:10.1016/j.measurement.2014.11.020

21. B.E. Roustom, G. Siné, G. Fóti, C. Comninellis, A novel method for the preparation of bi-metallic $(\mathrm{Pt}-\mathrm{Au})$ nanoparticles on boron doped diamond (BDD) substrate: application to the oxygen reduction reaction. J. Appl. Electrochem. 37(11), 1227-1236 (2007). doi:10.1007/s10800-007-9359-4

22. D. Duan, J. Liang, H. Liu, X. You, H. Wei, G. Wei, S. Liu, The effective carbon supported core-shell structure of Ni@Au catalysts for electro-oxidation of borohydride. Int. J. Hydrogen Energy 40(1), 488-500 (2015). doi:10.1016/j.ijhydene.2014.10. 101

23. N. Atar, T. Eren, M.L. Yola, H. Karimi-Maleh, B. Demirdogen, Magnetic iron oxide and iron oxide@gold nanoparticle anchored nitrogen and sulfur functionalized reduced graphene oxide electrocatalyst for methanol oxidation. RSC Adv. 5, 26402-26409 (2015). doi:10.1039/c5ra03735b

24. A. Azadbakht, A.R. Abbasi, Z. Derikvand, Z. Karimi, The electrochemical behavior of Au/AuNPs/PNA/ZnSe-QD/ACA electrode towards CySH oxidation. Nano-Micro Lett. 7(2), 152-164 (2015). doi:10.1007/s40820-014-0028-y

25. M. Taei, F. Hasanpour, H. Salavati, S.H. Banitaba, F. Kazemi, Simultaneous determination of cysteine, uric acid and tyrosine using Au-nanoparticles/poly(E)-4-(p-tolyldiazenyl)benzene- 
1,2,3-triol film modified glassy carbon electrode. Matter. Sci. Eng. C 59, 120-128 (2016). doi:10.1016/j.msec.2015.06.002

26. M.L. Yola, N. Atar, A novel voltammetric sensor based on gold nanoparticles involved in $p$-aminothiophenol functionalized multi-walled carbon nanotubes: application to the simultaneous determination of quercetin and rutin. Electrochim. Acta 119(6), 24-31 (2014). doi:10.1016/j.electacta.2013.12.028

27. M. Atmeh, B.E. Alcock-Earley, A conducting polymer/Ag nanoparticle composite as a nitrate sensor. J. Appl. Electrochem. 41(11), 1341-1347 (2011). doi:10.1007/s10800-011-0354-4

28. M. Chatenet, F. Micoud, I. Roche, E. Chainet, Kinetics of sodium borohydride direct oxidation and oxygen reduction in sodium hydroxide electrolyte Part $\mathrm{I}_{\text {. }} \mathrm{BH}_{4}$-electro-oxidation on $\mathrm{Au}$ and $\mathrm{Ag}$ catalysts. Electrochim. Acta 51(25), 5459-5467 (2006). doi:10. 1016/j.electacta.2006.02.015

29. Y. Lu, W. Chen, Size effect of silver nanoclusters on their catalytic activity for oxygen electro-reduction. J. Power Sources 197(1), 107-110 (2012). doi:10.1016/j.jpowsour.2011.09.033

30. S. Yallappa, J. Manjanna, B.L. Dhananjaya, U. Vishwanatha, B. Ravishankar, H. Gururaj, P. Niranjana, B.S. Hungund, Phytochemically functionalized $\mathrm{Cu}$ and $\mathrm{Ag}$ Nanoparticles embedded in MWCNTs for enhanced antimicrobial and anticancer properties. Nano-Micro Lett. 8(2), 120-130 (2016). doi:10.1007/s40820015-0066-0

31. Y. Jiang, J. Gang, S.Y. Xu, Contact mechanism of the Ag-doped trimolybdate nanowire as an antimicrobial agent. Nano-Micro Lett. 4(4), 228-234 (2012). doi:10.3786/nml.v4i4.p228-234

32. S.U. Karabiberoğlu, E.M. Ayan, Z. Dursun, Electroanalysis of caffeic acid in red wine and investigation of thermodynamic parameters using an $\mathrm{Ag}$ nanoparticles modified poly (thiophene) film glassy carbon electrode. Electroanalysis 25(8), 1933-1945 (2013). doi:10.1002/elan.201300091

33. M.F. Juárez, G. Soldano, H. Guesmi, F. Tielens, E. Santos, Catalytic properties of $\mathrm{Au}$ electrodes modified by an underlayer of Pd. Surf. Sci. 631, 235-247 (2015). doi:10.1016/j.susc.2014. 06.015

34. I. Banerjee, V. Kumaran, V. Santhanam, Synthesis and characterization of Au@Pt nanoparticles with ultrathin platinum overlayers. J. Phys. Chem. C 119(11), 5982-5987 (2015). doi:10. 1021/jp5113284

35. Q. Yi, J. Zhang, A. Chen, X. Liu, G. Xu, Z. Zhou, Activity of a novel titanium-supported bimetallic $\mathrm{PtSn} / \mathrm{Ti}$ electrode for electrocatalytic oxidation of formic acid and methanol. J. Appl. Electrochem. 38(5), 695-701 (2008). doi:10.1007/s10800-0089490-x

36. D.M.D. Anjos, K.B. Kokoh, J.M. LéGer, A.R. De Andrade, P. Olivi, G. Tremiliosi-Filho, Electrocatalytic oxidation of ethanol on Pt-Mo bimetallic electrodes in acid medium. J. Appl. Electrochem. 36(12), 1391-1397 (2006). doi:10.1007/s10800-0069222-z

37. R. Ojani, J.B. Raoof, E. Hasheminejad, One-step electroless deposition of $\mathrm{Pd} / \mathrm{Pt}$ bimetallic microstructures by galvanic replacement on copper substrate and investigation of its performance for the hydrogen evolution reaction. Int. J. Hydrogen Energy 38(1), 92-99 (2013). doi:10.1016/j.ijhydene.2012.10.015

38. M. Mohl, D. Dobo, A. Kukovecz, Z. Konya, K. Kordas, J. Wei, R. Vajtai, P.M. Ajayan, Formation of $\mathrm{CuPd}$ and $\mathrm{CuPt}$ bimetallic nanotubes by galvanic replacement reaction. J. Phys. Chem. C 115(19), 9403-9409 (2011). doi:10.1021/jp112128g

39. F.H. Ko, M.R. Tai, F.K. Liu, Y.C. Chang, Au-Ag core-shell nanoparticles with controllable shell thicknesses for the detection of adenosine by surface enhanced Raman scattering. Sens. Actuator B 211, 283-289 (2015). doi:10.1016/j.snb.2015.01.047

40. J.B. Raoof, R. Ojani, S. Rashid-Nadimi, Electrochemical synthesis of bimetallic Au@Pt nanoparticles supported on gold film electrode by means of self-assembled monolayer. J. Elecetroanal.
Chem. 641(1-2), 71-77 (2010). doi:10.1016/j.jelechem.2009.12. 018

41. Z. Dursun, Ş. Ulubay, B. Gelmez, F.N. Ertas, Electrocatalytic reduction of oxygen on a Pd ad-layer modified $\mathrm{Au}$ (111) electrode in alkaline solution. Catal. Lett. 132(1-2), 127-132 (2009). doi:10.1007/s10562-009-0058-0

42. K. Jayakumar, R. Rajesh, V. Dharuman, R. Venkatasan, J.H. Hahn, S.K. Pandian, Gold nano particle decorated graphene core first generation PAMAM dendrimer for label free electrochemical DNA hybridization sensing. Biosens. Bioelectron. 31(1), 406-412 (2012). doi:10.1016/j.bios.2011.11.001

43. Z. Li, G.L. Fan, Z.Q. Tan, Z.Q. Li, Q. Guo, D.B. Xiong, D. Zhang, A versatile method for uniform dispersion of nanocarbons in metal matrix based on electrostatic interactions. Nano-Micro Lett. 8(1), 54-60 (2016). doi:10.1007/s40820-015-0061-5

44. S. Jayabal, R. Ramaraj, Bimetallic Au/Ag nanorods embedded in functionalized silicate sol-gel matrix as an efficient catalyst for nitrobenzene reduction. Appl. Catal. A-Gen. 470(2), 369-375 (2014). doi:10.1016/j.apcata.2013.10.056

45. Q. Shi, G. Diao, S. Mu, The electrocatalytic oxidation of glucose on the bimetallic $\mathrm{Au}-\mathrm{Ag}$ particles-modified reduced graphene oxide electrodes in alkaline solutions. Electrochim. Acta 133(7), 335-346 (2014). doi:10.1016/j.ultsonch.2014.02.006

46. B. Neppolian, C. Wang, M. Ashokkumar, Sonochemically synthesized mono and bimetallic $\mathrm{Au}-\mathrm{Ag}$ reduced graphene oxide based nanocomposites with enhanced catalytic activity. Ultrason. Sonochem. 21(6), 1948-1953 (2014). doi:10.1016/j.ultsonch. 2014.02.006

47. C.-W. Yen, M.-L. Lin, A. Wang, S.-A. Chen, J.-M. Chen, C.-Y. Mou, $\mathrm{CO}$ oxidation catalyzed by $\mathrm{Au}-\mathrm{Ag}$ bimetallic nanoparticles supported in mesoporous silica. J. Phys. Chem. C 113(41), 17831-17839 (2009). doi:10.1021/jp9037683

48. T.-H. Tsai, S. Thiagarajan, S.-M. Chen, Green synthesized AuAg bimetallic nanoparticles modified electrodes for the amperometric detection of hydrogen peroxide. J. Appl. Electrochem. 40(12), 2071-2076 (2010). doi:10.1007/s10800-010-0188-5

49. L. Rahman, A. Shah, S.B. Khan, A.M. Asiri, H. Hussain et al., Synthesis, characterization, and application of $\mathrm{Au}-\mathrm{Ag}$ alloy nanoparticles for the sensing of an environmental toxin, pyrene. J. Appl. Electrochem. 45(5), 463-472 (2015). doi:10.1007/ s10800-015-0807-2

50. Ç.C. Koçak, Z. Dursun, Simultaneous determination of ascorbic acid, epinephrine and uric acid at over-oxidized poly ( $p$ aminophenol) film modified electrode. J. Electroanal. Chem. 694(2), 94-103 (2013). doi:10.1016/j.jelechem.2013.02.006

51. A. Bayler, A. Schier, G.A. Bowmaker, H. Schmidbaur, Gold is smaller than silver. crystal structures of [bis(trimesitylphosphine)gold(i)] and [bis(trimesitylphosphine)silver(i)] tetrafluoroborate. J. Am. Chem. Soc. 118(29), 7006-7007 (1996). doi:10. $1021 / \mathrm{ja} 961363 \mathrm{v}$

52. D. Zheng, C. Hu, T. Gan, X. Dang, S. Hu, Preparation and application of a novel vanillin sensor based on biosynthesis of $\mathrm{Au}-\mathrm{Ag}$ alloy nanoparticles. Sens. Actuator B 148(1), 247-252 (2010). doi:10.1016/j.snb.2010.04.031

53. Ç.C. Bakır, N. Sahin, R. Polat, Z. Dursun, Electrocatalytic reduction of oxygen on bimetallic copper-gold nanoparticlesmultiwalled carbon nanotube modified glassy carbon electrode in alkaline solution. J. Electroanal. Chem. 662(2), 275-280 (2011). doi:10.1016/j.jelechem.2011.06.016

54. X. Zhang, C. Wei, Y. Song, X. Song, Z. Sun, Nanoporous Ag$\mathrm{ZrO}_{2}$ composites prepared by chemical dealloying for borohydride electrooxidation. Int. J. Hydrogen Energy 39(28), 15646-15655 (2014). doi:10.1016/j.ijhydene.2014.07.102

55. D. Zhao, Y. Yu, C. $\mathrm{Xu}, \mathrm{A}$ sensitive electrochemical immunosensor for the detection of human chorionic gonadotropin 
based on a hierarchical nanoporous AuAg alloy. RSC Adv. 6, 87-93 (2016). doi:10.1039/c5ra24300a

56. Y. Zhang, G. Gao, Q. Qian, D. Cui, Chloroplasts-mediated biosynthesis of nanoscale $\mathrm{Au}-\mathrm{Ag}$ alloy for 2-butanone assay based on electrochemical sensor. Nanoscale Res. Lett. 7, 475-482 (2012). doi:10.1186/1556-276X-7-475

57. A.Q. Wang, J.H. Liu, S.D. Liu, T.S. Lin, C.Y. Mou, A novel efficient $\mathrm{Au}-\mathrm{Ag}$ alloy catalyst system: preparation, activity, and characterization. J. Catal. 233(1), 186-197 (2005). doi:10.1016/j. jcat.2005.04.028

58. E. Laviron, The use of linear potential sweep voltammetry and of A.C. voltammetry for the study of the surface electrochemical reaction of strongly adsorbed systems and redox modified electrodes. J. Electroanal. Chem. 100(1-2), 263-270 (1979). doi:10. 1016/S0022-0728(79)80167-9

59. W. Guo, M. Geng, L. Zhou, S. Chao, R. Yang, H. An, H. Liu, C. Cui, Multi-walled carbon nanotube modified electrode for sensitive determination of an anesthetic drug: tetracaine hydrochloride. Int. J. Electrochem. Sci. 8(4), 5369-5381 (2013)

60. A.J. Bard, L.R. Faulkner, Electrochemical Methods: Fundamentals and Application (Wiley, New York, 2001)
61. F.H.B. Lima, A.M. Pasqualeti, M.B.M. Concha, M. Chatenet, E.A. Ticianelli, Borohydride electrooxidation on $\mathrm{Au}$ and $\mathrm{Pt}$ electrodes. Electrochim. Acta 84(1), 202-212 (2012). doi:10. 1016/j.electacta.2012.05.030

62. H. Cheng, K. Scott, Determination of kinetic parameters for borohydride oxidation on a rotating $\mathrm{Au}$ disk electrode. Electrochim. Acta 51(17), 3429-3433 (2006). doi:10.1016/j.electacta. 2005.09.038

63. E. Gyenge, Electrooxidation of borohydride on platinum and gold electrodes: implications for direct borohydride fuel cells. Electrochim. Acta 49(6), 965-978 (2004). doi:10.1016/j.electacta. 2003.10.008

64. M.V. Mirkin, H. Yang, A.J. Bard, Borohydride oxidation at a gold electrode. J. Electrochem. Soc. 139(8), 2212-2217 (1992). doi:10.1149/1.2221204

65. J.L. Wei, X.Y. Wang, Y. Wang, Q.Q. Chen, F. Pei, Y.S. Wang, Investigation of carbon-supported $\mathrm{Au}$ hollow nanospheres as electrocatalyst for electrooxidation of sodium borohydride. Int J. Hydrogen Energy 34(8), 3360-3366 (2009). doi:10.1016/j. ijhydene.2009.02.014 